\title{
Making Sanctuary for the Divine: Exploring Melissa Raphael's Holocaust Theology
}

\author{
CHRISTOPHER PRAMUK \\ cpramuk@regis.edu \\ Regis University, Denver, CO 80221
}

A good life is infinitely greater than its dying .... What was very good is eternally good and stands as a witness to God's creation of a good world.

Melissa Raphael, The Female Face of God in Auschwitz

The first time I learned of Melissa Raphael's book, The Female Face of God in Auschwitz, ${ }^{1}$ was six or seven years ago when a reviewer of my book on Wisdom-Sophia and the divine feminine in the writings of Thomas Merton drew some parallels between what I was attempting theologically in that book, from a Christian perspective, and Raphael's work, from a Jewish. ${ }^{2}$ I read the book and was astonished by its depth, courage, and imaginative scope; it is easily one of the finest works of constructive theology I have read in the last decade. Since then I have tried to integrate something of Raphael's work into my classes whenever I treat the theodicy question. The book itself is a dense and difficult read. As an advanced work in Jewish feminist theology, the background Raphael presumes of her reader is well beyond what most undergraduates and even introductory graduate theology students may be prepared to handle. But every once in a while, as I tell graduate students, a book comes along that is worth "reaching up to," which is to say, worth the cost, both intellectually and emotionally, to go with an author where she wants to take her reader: in this case, into the terrible darkness of Auschwitz. It is worth it because on the other side of our efforts we are very likely to be changed, and our ideas about God forever transformed.

\footnotetext{
${ }^{1}$ Melissa Raphael, The Female Face of God in Auschwitz: A Jewish Feminist Theology of the Holocaust (New York: Routledge, 2003).

${ }^{2}$ Patrick Cousins, review of Sophia: The Hidden Christ of Thomas Merton (Collegeville, MN: Liturgical/Michael Glazier, 2009) by Christopher Pramuk, at http://www.catholicbooksreview.org/2010/pramuk.htm; Cousins' comparison to Raphael's work came in a personal email exchange following the publication of his review.
} 
While the book is difficult for non-specialists, Raphael's basic method is not difficult to reproduce in the classroom. At every turn her theological reading of Auschwitz - a sustained meditation, really_-begins with the stories of women's experiences in the camps. But she does not just recount the stories. As one of my students observed during a class discussion, the way Raphael does theology is something like a musician interpreting a score on the page: she attends not only to the notes but to the silences "between the notes" of women's memoirs from the camps, and she helps us, her readers, do the same. Though it is not possible here to do justice to the book's contributions, in what follows I will more or less reproduce the method I use in the classroom, introducing select passages organized around focused theological themes. By emphasizing the potential appeal of Raphael's work to undergraduates, I hope to persuade readers that The Female Face of God in Auschwitz merits greater attention in Christian and Catholic theological circles.

A final note by way of introduction: Raphael tells us in the book's preface that she wrote it for her daughter, realizing that by the time she "has grown up the Holocaust will have receded . . . into a world of visual and literary texts but almost beyond her direct knowing. . . .I would like some of what she might read to be mediated in ways less flawed by androcentrism than those books that have been available to me." She dedicates the book to her daughter "as a way of telling her how the Holocaust might be, not redeemed, but qualified; that is, not entirely a fall from hope - as it once was for me."3 For this Catholic reader, the book certainly resounds with hope, that is to say, with theological hope, a hopefulness centered in God and in human possibilities, though it is a hope that does not come cheaply. I can think of few greater aspirations as a father, theologian, and teacher than to pass on such a hope in some form or another to my own children and to my students.

\section{I. "A Staying There against Erasure": Women's Narratives from the Camps}

From the first pages Raphael makes it clear that she is responding to a range of influential Jewish post-Holocaust theologies, works written almost exclusively by men, which presume a patriarchal or androcentric framework. ${ }^{4}$ Like other feminist theologians, Jewish and Christian, she argues that patriarchal or exclusively male images, discourses, and practices in synagogue and church have sanctioned a great deal of injustice, misogyny, and violence in society, in no small part by

\footnotetext{
${ }^{3}$ Raphael, Female Face of God, x.

${ }^{4}$ For example, Richard Rubenstein, Eliezer Berkovits, Emil Fackenheim, Ignaz Maybaum, Arthur Cohen, and David Blumenthal, each of whom in distinct ways elevate divine omnipotence at the expense of God's immanence - perhaps in part, if understandably, to avoid advocating an immanent God who tries to protect the innocent and fails. Raphael is careful to avoid generalizing terms (e.g., see her note on "patriarchy," p. 168, n. 14) and summary judgments of particular post-Holocaust theologians without due examination. She repeatedly reminds the reader of the risks and fallibilities of her own project.
} 
obscuring the female face of God: God's nurturing, indwelling Presence known in the Jewish biblical and rabbinic tradition as Shekhinah. Patriarchal forces have veiled the divine feminine "to the point of disappearance," she argues, and nowhere more horrifically than in Auschwitz. Indeed it is not altogether surprising, she suggests, that traditional Jewish theology could not conceive how the allpowerful God of Moses and the prophets would have been so utterly powerless, so impotent, in the face of Auschwitz. In effect, traditional post-Holocaust approaches accuse God, argues Raphael, for not being patriarchal enough. ${ }^{5}$ Raphael wants to challenge traditional or popular default assumptions about how God's power and presence are (and are not) manifest in the world: "There has been too much asking 'where was God in Auschwitz?' and not enough 'who was God in Auschwitz." "By and large Holocaust theology, she asserts, "has not questioned its own basic model of God. It is my contention that it was a patriarchal model of God, not God-in-God's self, that failed Israel during the Holocaust."7

In truth, Raphael maintains, God was not wholly eclipsed in Auschwitz but was truly present in the relational acts of women who turned in compassion and bodily care toward one other, defying the most inhumane and desperate circumstances. With unsparing detail, she unearths the largely ignored stories of women in the camps who maintained the practices of Jewish prayer and ritual purification with whatever resources were available to them — not excluding their own bodily fluids where water was nowhere to be found. ${ }^{8}$ Within the barbed-wire enclosure of the camps, one woman's body bent in compassionate presence over another woman's body or the vulnerable body of a child formed an encircling space where the divine Presence could dwell, where God could be bodily reconciled with humanity over against the patriarchal god of raw power, the false and idolatrous god of nation-states and National Socialism. Even, if not especially, in Auschwitz, the most basic gestures of compassion constituted "a redemptive moment of human presence, a staying there against erasure" — not only for women in the camps, but through them, for God.

In one of the many extant memoirs Raphael cites, Auschwitz survivor Olga Lengyel describes a dormitory within the women's camp that contained a basin and a scrub brush. "No spectacle was more comforting than that provided by the women when they undertook to cleanse themselves thoroughly in the evening. They passed the single scrubbing brush to one another... That was our only way

\footnotetext{
${ }^{5}$ Raphael, Female Face of God, 35-37.

${ }^{6}$ Raphael, Female Face of God, 54.

${ }^{7}$ Raphael, Female Face of God, 5. While affirming a certain necessary agnosticism in theological discourse on the Holocaust - we simply do not know why such horrific things happened-Raphael insists the evidence does allow for the claim that patriarchal theological discourse fails to offer a persuasive response to the Shoah, much less consolation, "because it is predicated upon a model of God whose will and character shares significant elements of the alienated patriarchal worldview of its predicators. It does not and cannot mount a significant moral critique of the world that produced and inherited Auschwitz because it enjoys discursive and religious privileges within that world" (37).

${ }^{8}$ Raphael, Female Face of God, 68.

${ }^{9}$ Raphael, Female Face of God, 157.
} 
of waging war against the parasites... against every force that made us victims." ${ }^{10}$ In such rare moments of bodily cleansing, Raphael suggests, women kept "the mark of personhood, both human and divine," 11 from disappearing, at once reclaiming or making room, as it were, for the irruption of the holy. Much as the Sabbath and Jewish purity rituals signified the creation of a kind of sanctuary in time for Jews outside of the camps, to "take the time" to cleanse themselves and one another from filth within the camps was no less an act of Sabbath-making. "To be washed could be to be resurrected." compassion constituted acts of holy resistance, sacred in their fundamental structure of care for the divine-human person, irrespective of their practical utility, or perceived futility.

Raphael tells the story of a woman who, torn from her husband and children by SS guards immediately after arriving at the camp, falls weeping on the frozen ground "with the flaming crematoria before her," when she suddenly feels two hands lay a garment around her shoulders. An old Frenchwoman had stepped forward, wrapping her in her own cloak, whispering "It will be over and done soon, it will be over." ${ }^{13}$ She recalls another now-iconic story of an old woman who is remembered "for holding in her arms a motherless 1-year-old child as she stood at the edge of the communal pit, about to be shot with the rest of her village by Nazi troops. The old woman sang to the child and tickled him under the chin until he laughed with joy. Then they were shot." 14

\section{II. “Here I Am, I Am Here": The Contours of Divine-Human Presence}

The divine presence for Raphael is always relational, ever transitive, moving toward another. Like the old woman singing to the child, it says, "Here I am, I am here." To ask the question of God's presence in the midst of utter deprivation is not only to ask, "How was God made present to us? but also, and inseparably from that, "how did we make ourselves present to God?""15 For Raphael, the love reflected "between the lines" of women's stories in the camps is the "love of a

\footnotetext{
${ }^{10}$ Raphael, Female Face of God, 69. Raphael draws on a "core literature" of memoirs of five women-Olga Lengyel, Sara Nomberg-Przytyk, Isabella Leitner, Giuliana Tedeschi, and Bertha Ferderber-Salz - all of whom were deported to Auschwitz between January and December 1944. Carol P. Christ highlights in her review a range of reasons for using these memoirs with caution, not least the risk of imposing God-language and a feminist hermeneutic onto the accounts of women who did not themselves use such language. See Carol P. Christ, "Review: The Female Face of God in Auschwitz: A Jewish Feminist Theology of the Holocaust," in Journal of the American Academy of Religion 73.2 (2005): 577-80. While acknowledging such risks herself, Raphael judges the alternative risk to be greater, namely, the silence that closes over women's accounts and thus distorts the project of post-Holocaust theology. Christ seems to concur (578). Other reviewers, largely appreciative, include Zev Garber, Review of Biblical Literature (n.d.): 592-95; M. Grey, Feminist Theology 15.1 (2006): 124-26.

${ }^{11}$ Raphael, Female Face of God, 67.

${ }^{12}$ Raphael, Female Face of God, 69.

${ }^{13}$ Raphael, Female Face of God, 58.

${ }^{14}$ Raphael, Female Face of God, 58.

${ }^{15}$ Raphael, Female Face of God, 122-23.
} 
Mother-God, known to the tradition as (the) Shekhinah." 16 From the Hebrew "shakhan"- to be present or dwell as in a tabernacle, sanctuary or tent-the Shekhinah emerges in rabbinic literature as "an image of the female aspect of God caring for her people in exile." 17 Israel's God is "an accompanying God whose face or presence, as Shekhinah, 'She-Who-Dwells-Among-Us,' goes with Israel, in mourning, into her deepest exile, even if Israel cannot see her in the terrible crush." 18 By contrast, "the Father-God-the monarchical Man of War-was of little or no consolation or relevance" to the women whose memoirs form the narrative ground of Raphael's study. ${ }^{19}$ Like very few works that I have read, Raphael forces her reader to think deeply about the divine image in whose image we profess that human beings are made: which "god" are we really talking about?

To be clear, Auschwitz itself for Raphael "was not and never could be a city of sanctuary; there was no place on earth where a Jew was more exposed and vulnerable to harm. . . [There the] victimized female body was under attack: [it was] a ruined sanctuary that could offer little refuge to Shekhinah, and often none at all. The body/sanctuary was without immunity; it had been entered and defiled. Shekhinah was both exposed to the profane gaze and obscured by the covering marks of its profanation." And yet, conversely, she says, "the profane can be transformed into the holy by the blessings of sanctifying touch." ${ }^{20}$ Women who, as it were, set their faces against Auschwitz by becoming visible to one another could realize God's presence in conditions wholly unfit for persons. And it is in the becoming visible to one another that we become holy, set apart, indeed, eternal. "To be created in the image of a (divine) other entails that creation is necessarily relational - a face-to-face event - God making us present to one another. It follows, then, that the retrieval or even momentary restoration of a face is the restoration of presence. In the one last glimpse of a face turning back to look at us, the victims of the Holocaust did not and could not disappear." ${ }^{2}$

Jewish philosopher Emmanuel Levinas famously locates the epiphany (or "Trace") of God in the face of the human other. ${ }^{22}$ Citing Levinas and Abraham

\footnotetext{
${ }^{16}$ Raphael, Female Face of God, 117.

${ }^{17}$ Raphael, Female Face of God, 82.

${ }^{18}$ Raphael, Female Face of God, 6.

${ }^{19}$ Raphael, Female Face of God, 116. Raphael is careful here to note that this is "not to make a global historical claim about women's faith during this period."

${ }^{20}$ Raphael, Female Face of God, 83.

${ }^{21}$ Raphael, Female Face of God, 130. Acknowledging hiddenness as a prevailing characteristic of God in the Jewish tradition, Raphael nevertheless maintains that "hiddenness implies (undetectable) presence." And to be present is to be ever in "a positioning of one to the other" (88). Here Raphael's mystical, theopoetical, and apophatic sensibilities, ever in fruitful tension with the cataphatic impulse in theology, come to the fore.

22 "The epiphany of the Absolute Other is a face by which the Other challenges and commands me through his nakedness, through his destitution. He challenges me from his humility and from his height" (Transcendence and Height, 1962, cited in Emmanuel Levinas: Basic Philosophical Writings, eds. Peperzak, Critchley, and Bernasconi [Bloomington: Indiana University, 1996], 17). While Levinas takes pains to avoid straightforward theological language, the divinity of the Trace in the human other is nevertheless undeniable: "the trace is not just one more word: it is the proximity of God in the countenance of my fellowman" (Levinas, Entre Nous: Thinking-of-the-Other), trans. Michael B. Smith and Barbara Harshav [New York: Continuum, 2006, 50]). "The trace of the Other is
} 
Joshua Heschel, Raphael underscores the breakthrough of divine presence in the face-to-face encounter, even in Auschwitz, where "God and Israel were in equal need of redemption from the pit":

God could hardly find her way through the darkness - but the darkness was not her disappearance. However momentarily, the spark generated between the seeing and seen face was analogous to a Sabbath candle inviting God's presence - Shekhinah - into Auschwitz. Even the most infinitesimal spark of light was enough to illuminate - if only momentarily - the grey face of the other and so refract God into the toppling world. ${ }^{23}$

Here, as in other arresting passages throughout the book, Raphael describes her hermeneutical framework as "a theology of image, rather than a covenantal theology alone," explaining that "a theology of image precedes and underpins the mutuality and reciprocity of covenant." While the divine personality "is ontologically transcendent and other to human personality," the divine other "achieves immanence by its reflection." Divinity is "tended in the tended person. . . . God, in Auschwitz, was knowable in the moment of being seen in the face of the seen other." 24

It is important to note that Raphael's affirmation of the "spark" of divine presence stands not in opposition but in direct proportion to the perceived "disappearance" of God; both hinge on the razor's edge of human receptivity and freedom: "God cannot be known where there is no one who will turn her face to hers." 25 In suggesting that God "cannot be known" without a corresponding "turning" in compassion toward the other, Raphael clearly undermines if not rejects "the doctrines of omnipotent omnipresence that have given comfort to patriarchal theology." ${ }^{26}$ Just as Heschel insists that God's immanence within the earthly "sanctuary" of time and space is dependent on human partnership, Raphael insists that the flickering spark of hope and power of transformation in the world is not lit by a mighty Interventionist, but is "contingent upon mutuality and responsibility and is therefore dependent upon the presence and absence of conditions on earth that invite or repel the divine; that look out for the divine and human other, or turn their backs on them." ${ }^{27}$ To "realize God," wrote Martin Bu-

the heavy shadow of God, the God who commands, "Thou shalt not kill"' (Levinas, Difficult Freedom, trans. S. Hand [Baltimore: Johns Hopkins, 1990], p. 8f).

${ }^{23}$ Raphael, Female Face of God, 61.

${ }^{24}$ Raphael, Female Face of God, 88.

${ }^{25}$ Raphael, Female Face of God, 70.

${ }^{26}$ Raphael, Female Face of God, 70.

${ }^{27}$ Raphael, Female Face of God, 70. Raphael is careful to maintain God's transcendent "otherness" even while emphasizing God's radical immanence "in," and presence "to," human persons. "As Shekhinah, God's presence in Auschwitz was that of a God whose power was such that she could consent to be defiled by virtue of her immanence and still be God, then, now, and in the times to come." (85) At the same time, hers is not, she insists, a "quasi-Christian incarnational theology in which God's redemptive presence is that of the marked bodies of the victims, as if they were her garment of suffering flesh."(42) Carol Christ suggests that Raphael's attempt to articulate a vision of an 
ber, "means to prepare the world for God, as a place for His reality - to help the world become God-real." 28 Her reality-Shekhinah-was welcomed into Auschwitz, and became knowable, in the washing of the face. ${ }^{29}$

\section{III. "We Left the Camp Singing": Etty Hillesum}

Nowhere is the reclaiming of the divine "in the restoration of a face" more striking for me than in Raphael's reading of Etty Hillesum's story. A Dutch Jew who lived in Amsterdam during the Nazi occupation and was murdered in Auschwitz at age 29, Hillesum's war-time diaries, like those of the far more wellknown Anne Frank, survived the war. But Hillesum was significantly older than Frank, and her journals reflect the experience and hard-bought wisdom of a woman who had seen and suffered more of life. Two weeks before her arrest and deportation to the transit camp of Westerbork, she wrote the following, lines that have haunted me since I first read them some twenty-five years ago, and a passage which has similarly captured the attention of my students:

Sunday morning prayer. "Dear God, these are anxious times. Tonight for the first time I lay in the dark with burning eyes as scene after scene of human suffering passed before me. I shall promise You one thing, God, just one very small thing: I shall never burden my today with cares about my tomorrow, although that takes some practice. Each day is sufficient unto itself. I shall try to help You, God, to stop my strength ebbing away, though I cannot vouch for it in advance. But one thing is becoming increasingly clear to me: that You cannot help us, that we must help You to help ourselves. And that is all we can manage these days and also all that really matters: that we safeguard that little piece of You, God, in ourselves. And perhaps in others as well. . . . You cannot help us, but we must help You and defend Your dwelling place inside us to the last." 30

immanent, self-emptying God risks itself borrowing from patriarchal ideals of transcendence that she aims to move beyond (Christ, 579-80).

${ }^{28}$ Martin Buber, On Judaism (1923), cited in Raphael, Female Face of God, 61.

${ }^{29}$ Raphael is walking a fine line here. On the one hand, she suggests that the victimized female body was utterly (i.e., ontologically) profaned in Auschwitz: it was a "ruined sanctuary" where the divine being/image could no longer dwell. Here, it seems to me, her emphasis falls on a theology of covenant relationship, where holiness is predicated on human freedom's sacred vocation to prepare the way for the divine indwelling. On the other hand, more in accord with her "theology of image" —and more akin to a Christian incarnational anthropology — she suggests that "the ineradicable stamp of divine origin is how God sets apart persons, things, places and times as God's own and God's holiness is indestructible" (84). In this sense, the Nazis degradation of women in Auschwitz "could not, in fact, desecrate them for holiness" (83). Because holiness (the divine image) "is a category of willed relation, rather than being a material property of objects, holiness cannot be taken away from those objects by physical force" (83). While maintaining that hers is not a "quasi-Christian incarnational theology," Raphael's theology of image, much as in Heschel, seems to me so strong as to be functionally if not ontologically equivalent to a Christian incarnational view of the human person, even while Christian approaches differ widely, often dramatically, on the constitutive status of Jesus (or the Second Person) in a theology of creation and incarnation as related to the "imago Dei" in all persons.

${ }^{30}$ Etty Hillesum, An Interrupted Life and Letters from Westerbork (New York: Henry Holt, 
For many of my students, Christians who have never thought or been permitted to question traditional conceptions of the divine - a God who exists "out there," "above all," omnipotent, omniscient, omnipresent-Hillesum's prayerful assertion that "You cannot help us," and further that "we must help You," can be quite unsettling. If Hillesum's sense of God is authentic, if her experience of God is trustworthy, then what becomes of traditional notions of the divine?

In her exegesis of Hillesum's diaries, Raphael observes that the God to whom Hillesum prays "is a God who does not rescue the lives of the victims, but one who sustains the sufferers in their struggle to maintain, as long as possible, a life of dignity and self-respect." 31 Even more, as her Catholic biographer and editor Robert Ellsberg suggests, Hillesum seems to know intimately and place her trust in a God who calls on human beings to take suffering upon themselves "in solidarity with those who suffer." 32 This was not, as Ellsberg insists, a masochistic embrace of suffering for itself; rather it was a vocation "to redeem the suffering of humanity from within, by safeguarding 'that little piece of You, God, in ourselves." 33 But most striking, and perhaps what most defies rational or traditional theological explanation, Hillesum's compassion extends not only to her fellow Jews - and, at times, their German persecutors - but "even to the defenseless God whose survival depends on the work of human beings to defend the world from destruction." ${ }^{34}$ "There must be someone to live through it all," Hillesum writes in 1942, "and bear witness to the fact that God lived, even in these times. And why should I not be that witness?"35

I am especially moved, and moved as a theologian, by Raphael's suggestion that the very act of writing for many women during the Holocaust was a form of active resistance and relational presence, redeeming the divine, as it were, at the very moment of disintegration. Such witness - the solitary accounting of a life, with no assurances that one's written words will ever be received-reflects a spark of inner freedom that the Nazis were unable to extinguish. Etty Hillesum's

1996), 178. Compare to Trappist monk and spiritual writer Thomas Merton, who describes the heart of the religious calling as "to be human in this most inhuman of ages, to guard the image of man for it is the image of God." Thomas Merton, Raids on the Unspeakable (New York: New Directions, 1966), 6; emphasis original.

${ }^{31}$ Raphael, Female Face of God, 117, citing Rachel Feldhay Brenner.

${ }^{32}$ Robert Ellsberg, All Saints: Daily Reflections on Saints, Prophets, and Witnesses from Our Time (New York: Crossroad, 1997), 522.

${ }^{33}$ Ellsberg, All Saints, 522.

${ }^{34}$ Raphael, Female Face of God, 117.

${ }^{35}$ Etty: The Letters and Diaries of Etty Hillesum, 1941-1943, ed. Klaas A. D. Smelik, trans. Arnold J. Pomerans (Grand Rapids, MI: Eerdmans, 1986), 506. Commenting on this and other "harrowing" passages from Hillesum's 1942 diaries, Rowan Williams concludes that "what she believes she is doing is what can best be described as taking responsibility for God in the situation." "Perhaps the language jars," Williams admits, "though no more than Bonhoeffer's well-known poem on going to God in God's need rather than running to God out of one's own helplessness; or even Teresa of Avila's account in her Life of a conversion on encountering the image of Christ at the scourging pillar, and recognising a call simply to be in some sense visibly where he is." See Rowan Williams, "Religious Lives," Romanes Lecture, 2004, accessed 5/11/2017 at http://rowanwilliams.archbishopofcanterbury.org/articles.php/2101/romanes-lecture-oxford-religiouslives. 
last known writings were scribbled on a postcard thrown from the train that delivered her to Auschwitz. "We left the camp singing,"36 she wrote. But listen to what Raphael does with these five words. Hear what she hears theologically in this seemingly insignificant gesture, a postcard written and cast into the wind by a young Jewish woman on the way to certain death:

Even more than her diary, this textual fragment that is delivered to us over on the "safe" other side of the Holocaust is the means by which Hillesum sends the ineradicable humanity of that "we" back to us. As the Torah does for God, Hillesum's text-her inked words on paper - establish both her eternal presence and, as a surrogate for presence, her absence. Essentially, if not materially, her presence, like her postcard, will forever flutter toward us like a butterfly on the fresh breeze of a Dutch field in early autumn somewhere near Westerbork. And it is when the theologian kneels in the grass to retrieve that card that history and theology begin to unite - a process already underway in Hillesum's own writing. ${ }^{37}$

This passage offers a crucial window into Raphael's theological method, and a riveting test case for exploring what it means to "do theology" with students. For Raphael, theology both encompasses and transcends history. In particular, the remembrance of the dead is more than a mere historical recounting. To borrow from the Catholic tradition, it is a kind of anamnesis, an epiphanic calling forth, the invocation of a "real presence." In remembering Hillesum and many others like her, there is a very real sense-Raphael calls it eschatological ${ }^{38}$ - in which one may dare to say that the train that carried the victims to Auschwitz never arrived. "There is something about the lives of the dead and surviving Jews who have lived Jewishly (that is, humanely) which means that although their faces have disappeared they cannot be finally erased. Their gaze is steady; we simply need to know where to look." 39

And on this point, quite beautifully and unexpectedly for this Christian reader, Raphael gestures to the story of Jesus, another Jew killed well before his time:

Visiting Auschwitz or, indeed, the towns and cities of continental Europe, the story of words once spoken in a garden outside Jerusalem's city walls comes to mind. A young man asked the women who sought to anoint the body of the dead rabbi Jesus, why they were seeking the living among the dead: "He is not here .... He is going [on] before you." (Luke 24:5)

.... To say that European Jewry is not there, in Auschwitz, but here, is to say what, in the uttering, is almost platitudinous: that despite appearances, good is not consumed by evil; a good life is infinitely greater than its dying;

\footnotetext{
${ }^{36}$ Hillesum, An Interrupted Life, 360; Raphael, Female Face of God, 130.

${ }^{37}$ Raphael, Female Face of God, 130.

${ }^{38}$ Raphael, Female Face of God, 134, 139.

${ }^{39}$ Raphael, Female Face of God, 131.
} 
that what was very good is eternally good and stands as a witness to God's creation of a good world. ${ }^{40}$

For Raphael, here is the meaning of a redemption that both contains history and transcends it: "When Israel in Auschwitz answers the human and divine summons in the present tense, with the great 'Here I am' recorded of the biblical dialogue between God and humanity, it defies the genocidal attempt to deport Jewish existence into the past tense." 41 Of course, the prophetic "Here I am" carries forward into every moment for each of us as a question: Am I here? Am I listening? Am I awake to God's call toward love in the urgent moment that is now?

\section{IV. "A Tree Stripped of its Leaves": The Divine Presence in Nature}

There is one other aspect of the divine Presence that must be mentioned here, if briefly, and that is the call of God coming toward us from the Earth and from non-human creation. Raphael notes that when no person was capable of a kind word or compassionate touch amid the degradation of the camps, "inanimate natural objects could take on the functions of divine presence for women." She recounts Victor Frankl's story of a girl who told him as she lay dying that a bare chestnut tree "was the only friend she had in her loneliness and that she often talked to it." When Frankl asked the girl if the tree replied, she answered, "It said to me, 'I am here-I am here-I am life, eternal life." Raphael concludes: "If God has chosen Israel as God's vehicle of self-revelation then [such stories] must tell us something about the nature and posture of God's presence among us. It may seem little more than a tree stripped of its leaves by an untempered wind." 42 Even the face of the moon, as one woman wrote from Auschwitz, could embody the "unfailing presence" of the divine Mother, whose "smooth, round face" is always turned towards us, "even if it is darkened by shadow and cloud." 43 Here was a power, says Raphael, that "did not redeem by mighty intervention," but by silent presence and care:

The moment it appeared, peeping through the window into the sleeping block, I said a silent prayer to it. The cool, pale moonlight did not harm or

\footnotetext{
${ }^{40}$ Raphael, Female Face of God, 131.

${ }^{41}$ Raphael, Female Face of God, 131.

${ }^{42}$ Raphael, Female Face of God, 58, citing Victor Frankl, Man's Search for Meaning. The evocation of divine presence in a tree stripped bare may recall for Christian readers patristic meditations linking the Cross of Jesus with the Tree of Life in Genesis. Again Raphael is careful to distinguish between Shekhinah as "the real presence of a suffering God" and a "quasi-Christian incarnation of God crucified in Auschwitz." She cites Jurgen Moltmann's theology (The Crucified God) as a Christian depiction "that is close but not identical" to her own, noting that in Jewish understanding "the suffering is that of one who, being among us, suffers with us, but does not suffer vicariously for us" (5455). To be sure, great care must be taken not to conflate Jewish and Christian interpretations of a suffering God, particularly in the case of the Shoah. Much depends from the Christian side on precisely how Jesus' crucifixion is understood to be redemptive, as well as keeping in full view the Jewishness of Jesus and the various Judaisms that shaped the early church.

${ }^{43}$ Raphael, Female Face of God, 116; citing Bertha Ferderber-Salz.
} 
taunt us; on the contrary, it soothed and comforted us. Its light was as pale as we, who were considered dead during our lifetime. On nights when I could not sleep I would unburden my heart to it. "Soon you will disappear from window, travelling over the city," I whispered. "Please look in the windows of my little girls, caress their head with your cool lit light, because I cannot stroke them with a mother's loving hand. Be kind to me, and when you return to my window tomorrow night tell me about my children. Are they sleeping peacefully in the strange house in that hostile city?"44

Again, my students find such narratives riveting, especially when they are encouraged to probe their own memories of nature's wonder and palpable "presence" in their lives. To linger with such experiences, and still more to make room for sharing them with their peers in a classroom setting, is to invoke together a sensibility and a kind of language that exceeds the quotidian, utilitarian, or functionally superficial. It is to invite students gently, if perhaps with some "fear and trembling," into the realm of the mystical, the contemplative, the theopoetical. For students who respond to the invitation, such close readings of Raphael alongside the "text" of their own lives can yield unexpected gifts, not least the affirmation that their own experiences of the ineffable, while eluding verification or facile expression, are real, and trustworthy. They might even begin to awaken to the possibility that the almighty God redeems not "by mighty intervention"as many have been taught from childhood, and find more and more incredible as young adults - but by silent presence and relational care. Perhaps the mightiest face of God, like the face of a faithful parent, friend, or lover, is revealed to us in our moments of greatest weakness, fragility, and need. ${ }^{45}$

\section{Theological and Pedagogical Conclusions}

In the Torah and in much of the Jewish theological tradition, God's face is revered, and often feared, as something too great and holy to behold. In his encounter with YHWH after the destruction of the tablets, Moses is permitted only to gaze, as it were, on God's back, for "My face must not be seen" (Ex. 33:23). Reconsidering the tradition through women's death camp memoirs, Raphael offers a striking counter-reading: to have "seen only God's back" during the Holocaust was not a function of divine power or omnipotence but was revelatory of a God whose "humiliation and sorrow was such that he could not face us; could not bear the sight of us." ${ }^{, 46}$ The covenantal God is the God who desires to

\footnotetext{
${ }^{44}$ Raphael, Female Face of God, 116.

${ }^{45}$ In his enormously influential book, When Bad Things Happen to Good People (New York: Schocken, 1981), Rabbi Harold Kushner, writing after his own crisis of faith following the death of his son, concludes that there is no satisfactory answer to the theodicy problem, if by "answer" we mean "solution." What matters above all is the human response to suffering- "What are you going to do about it?"- which shifts our attention and our freedom into the present, and orients our imaginations toward healing the future.

${ }^{46}$ Raphael, Female Face of God, 50.
} 
become immanent in the evident "weakness" and fragility of human relationships: Shekhinah. For Raphael, the myriad first-person accounts of embodied relationships formed in the camps, however brief or fragmentary, haunt the margins of the historical record in ways that cannot be ignored. Women who, risking their own survival, cared for children not their own before and after the trains arrived; women helping other women in the frantic attempt to gather things necessary for survival; women who carried or pushed one another forward during the death marches: "keeping together is the holocaustal narrative." 47 Restoring the face of God in history was, and remains today, inseparable from restoring the face of the other.

There is a beautiful and far-reaching ethical commitment in the Jewish tradition called tikkun olam, a Hebrew phrase meaning "the reparation," the "making good," "the rescuing to make good of what is left of this smashed world." 48 Melissa Raphael gets it exactly right, I believe, when she concludes that the restoration or tikkun of the world "does not occupy a quantity of space and time; it is the theophanic possibility of a moment." 49 The fearful mystery of grace hinges precisely on the moment - the accumulated constellation of moments - in which we, and people we will never meet, say yes or no to love, when we create "a sanctuary for the spark of the divine presence that [saves] it from being extinguished." ${ }^{50}$ Describing her one-woman play adapted from Etty Hillesum's writings, New York actress Susan Stein suggests that "Etty's words, insights and beliefs reach out from the Holocaust and allow us to see the power of hope and individual thought in the most extreme circumstances. In her gentle yet forthright way, Etty asks us not to leave her at Auschwitz but to let her have a 'bit of a say' in what she hopes will be a new world." 51 What "say" shall we give the dead in forging our courage to envision a new world? Hillesum embodies a central Jewish insight that Christian theology has too often obscured: God asks, God invites, God needs our participation in the indwelling drama of love. The realization of God's own dream for the world, what Jesus calls the Reign of God, hinges on our "I am here," our receptiveness, our fiat, our participation. ${ }^{52}$

\footnotetext{
${ }^{47}$ Raphael, Female Face of God, 96.

${ }^{48}$ George Steiner, "To Speak of Walter Benjamin," in Benjamin Studies: Perception and Experience in Modernity (Amsterdam: Rodopi, 2002), 13-23, at 22.

${ }^{49}$ Raphael, Female Face of God, 80.

${ }^{50}$ Raphael, Female Face of God, 79.

${ }^{51}$ For Stein's remarkable work and witness to Hillesum's legacy, see http://www.ettyplay.org/. Regarding the risks of "over-interpreting" women's Holocaust memoirs (see n. 10 above) -in my case, for example, the risks of imposing a particularly Christian interpretation-Stein shared with me in an email exchange her worries "of imposing a Judaism on to Etty that wasn't there." In adapting Hillesum's writings for the stage, she sought the help of biblical scholars and others who helped guide her "to read Etty's diaries through a different lens."

${ }^{52}$ When Catholics and Orthodox Christians celebrate Mary's fiat, her "yes" to the divine initiativeand celebrate her theologically, iconically, liturgically, as Theotokos, Mother of God, in the most elevated cataphatic imagery - it is crucial to remember that Mary's attunement to the divine presence had long been prepared in her by the people Israel, whose stories resound everywhere with the call of covenantal co-responsibility in history. Mary's participation in the mystery of redemption is inseparable from that of her people; so it was for Jesus, and so it is for all of us. As Thomas Merton puts it,
} 
Clearly Raphael's case for the divine presence in Auschwitz does not hinge on empirical or otherwise rational analyses, as if hints and gestures of the good could cancel out the overwhelming weight of evil. Hers is not, as she writes, "a quantitative theology, contingent upon circumstance"; it is "a qualitative, ethical theology" ${ }^{\prime 3}$ in which "the truly numinous spectacle was not the horror of the flaming chimneys but the mysterium of human love that is stronger than death, the tremendum of its judgment upon demonic hate, and the fascinans of its calling God back into a world which had cast her out." ${ }^{, 54}$ Indeed, the sacramental or sophianic impulse-as I would call it in Catholic terms - is an impulse that "attaches very large meanings to very small signs." "Even the resistance of one person," professes Emil Fackenheim, "suffices to deny evil its victory."

Theologically, from God's side, as it were, Raphael's work reclaims a communal memory and experience of the divine that has too long been marginalized and hidden from "mainstream" Western theological, pedagogical, and certainly liturgical discourses and practices. As one of my graduate students concluded of the book, it has to do with our discovery of a God who "desires and all but insists on relationship with creation," and here he adds, with emphasis, "with the whole of creation. . . . Raphael helped me to comprehend God not as androcentric but as a deity that requires both masculine and feminine aspects to be expressed harmoniously within the worshipping community, and so be known as God in God's totality. This was already a notion I had explored, but Raphael took it to another level, and gave me the courage to do so." ${ }^{, 57}$ If images comprise a life-world, and theological images implicitly and often explicitly sanction that life-world, then surely the violent unraveling of the world in our time is inseparable from our willful sundering of God. In the words of theologian Rita Gross, "When the masculine and the feminine aspect of God have been reunited and the female half

here with reference to Gandhi's inseparability from Hinduism and the people of India, "The spiritual life of one person is simply the life of all manifesting itself in him" (Thomas Merton, Gandhi on NonViolence [New York: New Directions, 1965], 11). It would be difficult to overstate how much the severing of the constitutive relationship between Christianity and Judaism in the imaginations of Christians throughout history - theologically, iconically, liturgically - has made for disastrous consequences, for Jews certainly, and in distinctively tragic ways for Christians.

${ }^{53}$ Raphael, Female Face of God, 71.

${ }^{54}$ Raphael, Female Face of God, 74; with a nod to Rudolph Otto's famous description (The Idea of the Holy) of religious experience as the mysterium tremendum et fascinans.

${ }^{55}$ Raphael, Female Face of God, 139.

${ }^{56}$ Cited in Raphael, Female Face of God, 131. I know of few better resources for unpacking this beautiful but deeply paradoxical religious insight in the classroom than Harold Kushner's video lecture, "When Bad Things Happen to Good People" (Charlotte: Oblate Media, 2006), based on his bestselling book. Flush with stories of ordinary people he has met in his pastoral work, for Kushner the really "big miracles" are not dramatic manifestations like the parting of the Red Sea but "when timid people become brave" and reach out to comfort suffering others. "God comes to us through the incarnation of caring people," he says, citing the Hasidic saying, "Human beings are God's language." Kushner confesses that he can still believe in God because he is "constantly seeing ordinary people do extraordinary things," things that would seem impossible in the face of crippling grief: choosing to love, forgive, and build a better world.

${ }^{57}$ Harold Thomas, used with permission. 
of humanity has been returned from exile, we will begin to have our tikkun. The world will be repaired." ${ }^{, 58}$

In sum, the remembrance of the feminine divine opens up imaginings of God "that transcend the associations of power and masculinity that usually accompany Western God-images." ${ }^{, 59}$ Raphael joins a form of subversive imagery (God as Shekinah) with subversive rhetoric (women's death camp narratives and her own theopoetics) that renders the apokalypsis of God in a powerfully new key: the irruption of hope amid hopelessness, the un-prosing of alienating discourse about "God" and the reification of false gods in the world. What Catholic theologian Patrick Cousins observes of the Wisdom-Sophia tradition in the Christian tradition may also be said of Shekhinah in the Jewish: "The very hiddenness of this sophianic vision is its strength - it is too weak to be brought to the center of a system of control, even a theological system, so it remains on the edge where it belongs, pushed out of the world, uncompromised by abstractions that lose sight of the real people who are chewed up by the machinery of power."60 Raphael never loses sight of the "real people" buried beneath the inexplicable horrors of the Shoah. At every turn her thesis is rendered with intellectual humility and kneeling deference before the "gray faces" of the dead. To borrow again from an undergraduate theology major: "Finishing this book was not about coming to a new understanding of the Holocaust that was suddenly beautiful and full of light. It was about coming to a new understanding of theology, of the power of the feminine act, and of the restoration of the memory of persons and the recognition of the feminine presence of God." 61

Theodicy is not the only lens through which one might approach Raphael's work with students, but it seems to me the most powerful entrée into the deep question of God and other related questions: Jewish and Christian understandings of theological anthropology, covenantal theology, Earth as a locus of divine presence, the spirituality of Jesus, protest atheism, and so on. Because the notion of the Shekhinah and the divine feminine is quite new and often strange to many of my predominantly Christian and Catholic students, I typically introduce Raphael's work only after we've wrestled with the theodicy question as such, and they've begun to recognize the many contradictions inherent to a patriarchal or

\footnotetext{
${ }^{58}$ Rita Gross, cited in Raphael, Female Face of God, 150. A convert to Judaism from Lutheranism in the 1960s, who then became a Buddhist in the 1970s, Rita Gross (d. 2015) was widely celebrated at her death as the leading Buddhist feminist theologian in the United States, though she never renounced her Jewish identity.

${ }^{59}$ Cousins, review of Pramuk, Sophia.

${ }^{60}$ Cousins, review of Pramuk, Sophia. For further exploration of Raphael's theology in dialogue with the Christian Wisdom-Sophia tradition and other contemporary expressions of the feminine divine, see Christopher Pramuk, "Theodicy and the Feminine Divine: Thomas Merton's 'Hagia Sophia' in Dialogue with Western Theology," Theological Studies 77:1 (March 2016); and Christopher Pramuk, "Presences," in Hope Sings, So Beautiful: Graced Encounters Across the Color Line (Collegeville, MN: Liturgical, 2013).

${ }^{61}$ I am grateful to Katie Geckle, formerly an undergraduate theology major at Xavier University, whose final paper on Raphael inspired me not a little in the conception and writing of this paper.
} 
literally male understanding of God. ${ }^{62}$ With undergraduates, I've found that it is enough to extract short excerpts of women's narratives from the book and then to help students get inside Raphael's subsequent theological reading of those stories. I say "get inside" because so much of the book, as noted above, is theopoetical in nature. The intensity of the subject matter is such that I try not to introduce it early in the semester. To engage The Female Face of God in Auschwitz in the Christian or Catholic theology classroom is to open up spaces for profoundly contemplative, sometimes harrowing, theopoetical discovery.

On this point I'd like to give the penultimate word to a graduate student, from his final review essay on Raphael's book. He writes:

Auschwitz-Birkenau is not a beautiful place. It was not a hopeful place. It was not a loving place. However, the women who suffered there but still showed some sort of care to others ensured that the tender nearness of God was present. In those camps, the women who shared just a caring touch shared a loving touch of God. The lens of theology magnifies this simple gesture. That simple touch, often taken for granted, becomes a touch of beauty to those in a despairing place. The hope that the Nazis sought to vanquish was given spark by women being present to each other. Love is found in community; hope is fostered by community; beauty is found in community. Theology is the foundation in which a community of sufferers is humanized in the midst of degrading suffering. ${ }^{63}$

The German Catholic theologian Johann Baptist Metz, haunted by his own childhood memories of the Second World War, has asserted that Christians can pray after Auschwitz only because there were Jews who prayed in Auschwitz. ${ }^{64}$ Paraphrasing Metz, I would put it this way: human beings can pray after Auschwitz because there were human beings who remained humane in Auschwitz. I agree with Melissa Raphael: "A good life is infinitely greater than its dying ...

\footnotetext{
${ }^{62}$ In addition to Raphael and Kushner, other resources I use to interrogate traditional theodicies in the classroom include Elie Wiesel's Night; Fyodor Dostoyevsky's "Rebellion," from The Brothers Karamozov; Natalie Kertes Weaver, The Theology of Suffering and Death (Routledge, 2012); Christopher Pramuk, "How Long O Lord? Interfaith Perspectives on Suffering and Grace," New Theology Review 17:4 (Nov 2004): 67-75; and select poems of Paul Celan. A course I teach in "Black Literature and Faith" employs classic texts, poetry, and music from the African American tradition that immerse students in the theodicy problem hidden, as it were, right under their noses. Select resources I have used to introduce the feminine divine include Sandra Schneiders, Women and the Word: The Gender of God in the New Testament and the Spirituality of Women (New York: Paulist, 1986); Leo Lefebure, "The Wisdom of God: Sophia and Christian Theology," Christian Century (Sep 1994); Joyce Rupp, "Desperately Seeking Sophia," US Catholic (July 2008); Andrew Greeley, "The Mother Love of God," in The Catholic Imagination (Berkeley: University of California, 2003); Maya Angelou, And Still I Rise (New York: Random House, 1978); Sue Monk Kidd, The Secret Life of Bees (New York: Penguin, 2003; feature film, dir. Gina Prince-Bythewood [Twentieth Century Fox, 2008)]).

${ }^{63}$ Harold Thomas, used with permission.

${ }^{64}$ Johann Baptist Metz, A Passion for God: The Mystical-Political Dimension of Christianity, trans. J. Matthew Ashley (Mahwah, NJ: Paulist, 1998), 1-2; 63; 122-23.
} 
What was very good is eternally good and stands as a witness to God's creation of a good world." 65

${ }^{65}$ Raphael, Female Face of God, 131. 